\title{
PÄÄKIRJOITUS
}

TIINA IKONEN

\section{Vapautuksen teologia diakonisen kirkon esikuvana}

Tuluvana syksynä ilmestyneet kirkon nelivuotiskertomus Uskonto arjessa ja
jublassa. Suomen evankelis-luterilainen kirkko vuosina 2016-2019 ja Diakoniabarometri 2020 Aina uuden edessä luotaavat molemmat diakonian roolia yhteiskunnassa. Toiminnallaan ja valinnoillaan kirkko on jatkuvassa vuorovaikutuksessa toimintaympäristönsä kanssa. Kyse ei kuitenkaan ole ainoastaan reagoinnista ympärillä tapahtuvaan vaan toiminnan tavoitteiden jatkuvasta arvioimisesta ja toivon rakentamisesta.

Molemmissa diakoniaa tarkastelevissa, kirkon itsensä toteuttamissa, tutkimuksissa nostetaan esille kysymys kirkon perustehtävästä ja missiosta. Diakonia nähdään kirkon kokonaisvaltaiseen missioon kuuluvana tehtävänä - ja samalla kirkon koko toimintaa läpäisevänä ulottuvuutena. Diakoniassa yhdistyvät kirkon hengellinen luonne ja yhteiskunnallinen vaikuttaminen. Näin katsottuna kirkko nähdään ytimeltään diakonisena kirkkona, joka valinnoillaan vaikuttaa yhteiskunnassa esimerkiksi tasa-arvon edistäjänä ja ilmastokeskusteluun osallistujana. Diakoninen kirkko liittyy käsitteenä keskusteluun, jota ekumeenisissa yhteyksissä ja esimerkiksi Luterilaisen maailmanliiton piirissä on käyty etenkin 1980-luvun lopulta saakka.

Nyt käsillä olevat kirkon arvopohjaa ja toimintaa tarkastelevat tutkimukset tuovat tärkeän lisän kirkon perustehtävän ja itseymmärryksen tarkasteluun. Teorian - ja teologian - tasolla ollut keskustelu saa lihaa luidensa päälle, kun niin kirkon työntekijöiltä ja luottamushenkilöiltä kuin kaikilta suoma- 
laisilta on kysytty mielipiteitä ja kokemuksia kirkon toiminnasta sen lähtökohdista.

Diakonisen kirkon itseymmärryksen kuvaaminen molemmissa tutkimuksissa vapautuksen teologiana on rohkea avaus kirkon arvolähtöisen yhteiskunnallisen vaikuttamisen suuntaan. Vapautuksen teologiassa kristillistä opetusta tulkitaan vahvasti yhteiskunnallisessa kontekstissa ja niiden näkökulmasta, jotka yhteiskunnassa ovat paitsiossa tai joita sorretaan. Vapautuksen teologiaan liittyy olennaisena yhteiskunnan toimintaan ja rakenteisiin vaikuttaminen. Diakoninen kirkko ei voi jäädä vierestä seuraajaksi.

Diakonian tutkimuksen seura määrittelee itsensä monitieteiseksi diakoniaa ilmiöpohjaisesti tarkastelevaksi tieteelliseksi seuraksi. Seuran julkaisutoiminta on paikka tuoda esille ajankohtaista diakonia-alan tutkimusta, on se sitten katsomuksellisten toimijoiden valintojen ja toimintamallien analysoivaa tarkastelua tai diakoniailmiötä eri tieteenalojen näkökulmista määrittävää tutkimusta. Tässä numerossa tarkastellaan diakoniaan liittyvää ihmisten välistä kohtaamista hyvin monesta näkökulmasta. Esillä ovat muun muassa hautatahdon toteuttamiseen liittyvät lähisuhteet ja itselle vieraaksi koetun ihmisen kohtaaminen.

Diakoninen kirkko on vahvasti itseään reflektoiva ja kehittävä kirkko. Kehittämistyöhön tarvitaan sekä tutkimustietoa ja käsitteellistä jäsentämistä että avoimuutta tuoda esille ja yhdessä arvioida tehtyä tutkimusta. Diakoniailmiön taustalla ovat lähimmäisenrakkauden ja ihmisten yhdenvertaisuuden vaatimukset. Diakoniassa tutkimus ja vaikuttaminen kuuluvat vahvasti yhteen. Diakonian teologiaa ei tehdä ainoastaan teoreettisin sanankääntein vaan sitä rakennetaan elämällä ja tekemällä valintoja. Näin ollen diakonian teologia on aina kontekstuaalista eivätkä siitä kumpuavat teot voi tulla valmiiksi tai tyhjennetyiksi. Diakonian perusluonteeseen kuuluu olla aina uuden edessä, kuten Diakoniabarometrissa 2020 osuvasti tiivistetään. 